\title{
Technological Hazards during Armed Conflicts
}

\author{
The Case of the SAFER Oil Tanker in Yemen
}

\author{
Mara Tignino*
}

\section{1 \\ Introduction}

This paper focuses on the legal framework applicable to potential technological disasters during an armed conflict. In particular, it focuses on the case study of the SAFE R oil tanker in Yemen. The SAFE R is a Floating Storage and Offloading (FSO) oil tanker anchored approximately 6o kilometers from the west coast of Yemen. The oil tanker is legally owned by the national oil company, the Safer Exploration \& Production Operation Company (sEPOC). Currently, the Houthis control the waters where the SAFER is anchored. ${ }^{1}$ Before the armed conflict in 2014, this tanker was used to store and export oil from the fields by SEPOC. Since then, the oil tanker has been almost abandoned by the company. While during its functioning, the vessel counted almost one hundred people of the crew, there are only a few employees of SEPOC who are monitored by surveillance cameras installed by the Houthis. The control exercised by the Houthis has diminished the capacity of the crew to work independently. Since September 2O2O, SEPOC declared that the company does not exercise anymore an effective control over the tanker. ${ }^{2}$

The tanker is still holding 1.148 million barrels of crude oil which is already starting to spill. ${ }^{3}$ After many years of neglect and little or no maintenance by SEPOC, the ship is in a deplorable state of repair and currently presents a significant risk to the people and environment of the Red Sea. If prevention measures are not implemented shortly, there is a real risk of a severe environmental and humanitarian disaster in Yemen. An oil spill would have large

* Reader at Department of Public International Law and International Organization (INPU B), Faculty of Law, University of Geneva.

1 UN News, 'Questions and answers about the UN Mission to the SAFEr Oil Tanker in Yemen' (30 December 2020) <https://news.un.org/en/story/2020/12/1081162> last accessed (as any subsequent URL) on 23 July 2021.

2 United Nations Security Council, 'Final Report of the Panel of Experts on Yemen', UN Doc S/2021/79 (25 January 2021), para. 13 <https://www.securitycouncilreport.org/atf/cf $/ \% 7$ B65 BFCF9B-6D27-4E9C-8CD3-CF6E4FF96FF9\% $\%$ D/S_2O21_79.pdf $>$.

3 UN Security Council, 'Press Release', sc/14254, (15 July 2020) <https:/www.un.org/press/ en/2020/sc14254.doc.htm>. 
impacts and will aggravate the living conditions of the population in Yemen who already suffers from a protracted armed conflict.

Responses to other environmental disasters in the region may guide action in Yemen. In another armed conflict, Israeli forces bombed the Jiyeh thermal power plant causing 15.000 tons of heavy fuel oil to spill into the Mediterranean Sea, directly affecting approximately $150 \mathrm{~km}$ of the Lebanese coastline and 7 $\mathrm{km}$ of the Syrian shoreline. ${ }^{4}$ In July 2006, Lebanon requested assistance about a 'massive amount of oil spills along the coastlines' to the Regional Marine Pollution Emergency Response Center for the Mediterranean Sea (REMPEC). ${ }^{5}$ The consequences of the disaster in Yemen would be more significant than the oil spill in Lebanon and would have impacts on both the environment and the local communities dependent on the Red Sea ecosystem.

The legal frameworks that can be applied to the SAFER oil tanker include principles and rules of international humanitarian law ( $\mathrm{IHL})$, international disaster law, and international environmental law. Disaster preparedness, the need for a technical assessment to conduct maintenance and repair, and the dismantlement of the tanker in an environmentally sound manner are particularly crucial in the context of the analysis of this case study. A large oil spill from the SAFER tanker would cause serious environmental damage and impact the Yemeni population. A potential oil spill could affect the living conditions of the communities dependent on the Red Sea ecosystems for their livelihoods. Moreover, the port of Hodeidah could also be closed if a spill occurs. ${ }^{6}$ In the case of an explosion, caused by the accumulation of gas in the tanker, hundreds of kilometers of agricultural land in Yemen could also be polluted. ${ }^{7}$

In light of the foregoing, the paper first presents the risks posed by the SAFER oil tanker to the environment as well as the health and livelihoods of

4 Regional Marine Pollution Emergency Response Center for the Mediterranean Sea (REMPEC), 'REMPEC'S Involvement in the Marine Pollution Incident in the Eastern Mediterranean During the Summer 2006, Note by the Secretariat', REMPEC/WG.28/9/2, paras. 1-2 (22 March 2007).

5 Ibid., para. 3 .

6 Security Council Report What's in Blue, 'Yemen: Briefing and Consultations on the Fso Safer Oil Tanker' (3 June 2021) <https://www.securitycouncilreport.org/whatsinblue/2021/o6/ yemen-briefing-and-consultations-on-the-fso-safer-oil-tanker.php> (The Director of the UN Environment Programme (UNEP) and the Under-Secretary-General for Humanitarian Affairs noted 'the potentially devastating humanitarian and economic consequences of the FSO SAFER's deteriorating condition. The port of Hodeidah, which receives the bulk of food and fuel imports for northern Yemen, where most Yemenis live, could be closed for up to six months in the event of a spill. International shipping through the Red Sea could also be affected').

7 Ibid. 
the population of Yemen. Then, the paper focuses on the various legal frameworks applicable to the SAFER oil tanker. As the paper will note, the role of IHL is limited in the case examined. The primary focus of $\mathrm{IHL}$ is on the humanitarian assistance provided to the civilian population and does not contain pertinent principles to prevent an environmental disaster even where there are substantial impacts on the community. Principles and instruments of international disaster law and international environmental law, on the other hand, are more helpful to prevent the risks of a potential disaster in the Red Sea even when the primary focus is on the environment and not the community. In this context, the paper will take into account the UN Convention on the Law of the Sea (UNCLOS) $)^{8}$ and pertinent regional environmental frameworks, including the Regional Convention for the Conservation of the Red Sea and Gulf of Aden Environment (Jeddah Convention) and the Protocol concerning Regional Cooperation in Combating Pollution by Oil and Other Harmful Substances in Cases of Emergency. ${ }^{9}$ The paper will also consider the work of the International Law Commission (ILC), in particular in the context of the protection of persons in the event of disasters (ILC Draft Articles on Disasters) and the prevention of transboundary harm from hazardous activities (ILC Draft Articles on Prevention). ${ }^{10}$ As the paper will demonstrate, there is an urgent need to deploy a field mission to assess the damages to the SAFER and start the loading of the oil barrels and the dismantling of the ship. An environmental disaster caused by an explosion of the oil tanker would exacerbate the current humanitarian crisis of Yemen.

\section{The Armed Conflict in Yemen}

After the Houthi insurgents took control of the capital Sana'a in 2014, there are multiple and overlapping non-international armed conflicts in Yemen. ${ }^{11}$ Over the years, the government of Yemen has lost control of territory to both

8 UN Convention on the Law of the Sea (UNCLOS), 10 December 1982.

9 Regional Convention for the Conservation of the Red Sea and Gulf of Aden Environment, 14 February 1982; Protocol concerning Regional Cooperation in Combating Pollution by Oil and Other Harmful Substances in Cases of Emergency, 27 August 1982.

10 ILC, 'Draft articles on the protection of persons in the event of disasters, Yearbook of the International Law Commission', 2016, vol. II (Part Two); ILC, 'Draft articles on Prevention of Transboundary Harm from Hazardous Activities, Yearbook of the International Law Commission', 2001, vol. II (Part Two).

11 See Rule of Law in Armed Conflict (RULAC), 'Non-international armed conflicts in Yemen' (15 April 2021) <https://www.rulac.org/browse/conflicts/non-international-armed -conflicts-in-yemen>. 
the Houthis and the Southern Transitional Council (STC). In 202O, there was a significant escalation in hostilities and the Houthis gained strategic territory. ${ }^{12}$ With the aim to restore the recognized government to power, an international coalition has also led indiscriminate airstrikes with disastrous consequences on critical civilian infrastructure and the population of Yemen..$^{13}$ After seven years of conflict, Yemen remains the world's worst current humanitarian crisis. ${ }^{14}$ Since the armed conflict escalated in 2015, the conditions of the country have collapsed, resulting in internal displacement, food insecurity, and cholera outbreaks, which have been exacerbated in the last two years by Covid-19. ${ }^{15}$

The United Nations (UN) has been trying to facilitate a peace negotiation between the recognized government of Yemen and the Houthi insurgents since the beginning of the war. ${ }^{16}$ In December 2018, the UN Security Council (UNSC) endorsed the Stockholm agreement under resolution $2451 .{ }^{17}$ One of the main successes of this agreement is the prisoners exchange between the two parties. However, in 2019, the fragile ceasefire agreed between the parties did not last. ${ }^{18}$ In February 2021, the UNSC stressed the need for de-escalation across Yemen and a nationwide ceasefire, and 'called for the implementation of the Secretary General's Global Ceasefire call as detailed in resolution $2532(2020)$, as well as his 25 March 2020 call for an immediate cessation of hostilities in Yemen.' ${ }^{19}$ In April 2021, the UN Special Envoy for Yemen, Martin Griffiths, appealed to the warring parties to implement a national ceasefire and agree on a date for peace

12 Final Report of the Panel of Experts on Yemen (n 2) paras. 37-42.

13 Jeannie Sowers and Erika Weinthal, 'Humanitarian Challenges and the Targeting of Civilian Infrastructure in the Yemen War' (2021) 97 International Affairs 1, 157, 157-177.

14 Islamic Relief, 'Famine Looming in Yemen Again as a Growing Number of Young Children Die of Malnutrition' (18 April 2021) <https://reliefweb.int/report/yemen/famine-looming -yemen-again-growing-number-young-children-die-malnutrition>.

15 UN Population Fund (UNFPA), 'After years of conflict, Yemen remains the world's humanitarian crisis, a UNFPA 2021 appeals shows' (7 December 2020) <https://reliefweb.int/ report/yemen/after-years-conflict-yemen-remains-world-s-worst-humanitarian-crisis -unfpa-2021-appeal>; See also, Human Rights Council, 'Oral Update of the Group of Eminent Experts on Yemen to the 46th Session of the Human Rights Council' (25 February 2021) <https://www.ohchr.org/EN/HRBodies/HRC/Pages/NewsDetail.aspx?NewsID=268oo \&LangID $=\mathrm{E}>$.

16 Al Jazeera, 'Yemen's Exiled President Hadi calls for new uprising' (5 December 2017) https://www.aljazeera.com/news/2017/12/5/yemens-exiled-president-hadi-calls-for-new -uprising.

17 UNSC Res 2541 (21 December 2018) UN Doc S/RES/2451, para. 2.

18 Ibrahim Jalal, 'Yemen's Stockholm Agreement One Year On: Imaginary Progress?' (Middle East Institute, 22 January 2020) <https://www.mei.edu/publications/yemens-stockholm -agreement-one-year-imaginary-progress $>$.

19 UNSC Res 2564 (25 February 2021) UN Doc S/Res/2564; See also UNSC Res 2511 (25 February 2020) UN Doc S/RES/2511. 
talks. A global ceasefire would set the country on a pathway towards peace. ${ }^{20}$ Moreover, unimpeded access to the ports and the airport in Sana'a is essential to allow access to humanitarian relief activities in the country.

\subsection{The Humanitarian and Environmental Threats Posed by the SAFER Oil Vessel}

In the context of the protracted armed conflict in Yemen, there is also the risk of an environmental disaster caused by the oil spill of the SAFER tanker. The quantity of the oil barrels stored in the SAFER is about four times as much oil as spilled from the Exxon Valdez in 1989. SAFER's structure, equipment, and operating systems are deteriorating, leaving the tanker at risk of leaking, exploding, or catching fire. ${ }^{21}$

As noted by the UN Panel of Experts on Yemen in January 2021, the oil spill would have catastrophic environmental and humanitarian consequences. ${ }^{22}$ The spill would severely impact the Red Sea ecosystem on which almost 30 million people depend, including at least 1.6 million Yemenis. An oil spill would impact Red Sea countries, including Djibouti, Eritrea, and Saudi Arabia. All the fisheries along the Yemeni west coast would be impacted and the livelihoods of the fishing communities would collapse. This would be particularly catastrophic given that $90 \%$ of this population is already dependent on humanitarian aid. Moreover, if a fire erupts on SAFER, more than 8.4 million people could be exposed to harmful levels of pollutants. ${ }^{23}$

An environmental disaster linked to an oil spill or explosion of the SAFER tanker could also lead to the closure of the port of Hodeidah, which would render the delivery of vital humanitarian aid to Yemenis even more difficult. A majority of imports to the population enter through this port. This is a vital lifeline for millions of Yemenis who depend on commercial imports and humanitarian aid. The risk of the port closing would be even more alarming when Yemen is facing a risk of famine and would exacerbate the levels of fighting. ${ }^{24}$

An oil spill or a fire on the SAFER would have both environmental and humanitarian consequences for the civilian population. Already, 90\% of Yemen's food is imported. Some three-quarters of solid-food imports enter the country through the Houthi-controlled port of Hodeidah. The redirection of fuel

20 UN News, 'UN envoy highlights diplomatic unity, as key to help end Yemen war' (15 April 2021) <https://news.un.org/en/story/2021/04/1089812>.

21 Final Report of the Panel of Experts on Yemen (n 2) 170-173.

22 Ibid.

23 Questions and answers about the UN Mission to the SAFER Oil Tanker in Yemen' ( $\mathrm{n}_{1}$ ).

24 Ibid. 
and food imports to the southern port of Aden would pose acute challenges in a country where armed conflicts already severely impede the movement of goods, and would lead to spikes in food and fuel prices. ${ }^{25}$

\subsection{The Negotiations regarding the SAFE R Oil Tanker Crisis}

In 2016, the issue of the SAFER was raised for the first time by the parties to the conflict due to concerns that it represented a potential threat to the ecology of the Red Sea. Because the lead UN agency with continuous communications with the Houthis in Sana'a was the Office for the Coordination of Humanitarian Affairs (OCHA), this UN body led initial discussions with the Houthis on the SAFER. ${ }^{26}$

In 2017, and after several rounds of discussion, the Houthis and the government of Yemen agreed in principle to a technical assessment of the vessel and initial repairs. The assessment mission would inform the next steps and form the basis for an agreement with the parties. This is likely to include the safe extraction and sale of the cargo as well as the removal of the vessel for scrap. ${ }^{27}$

At the beginning of 2018, the Houthis and the government of Yemen sent official letters to the UN Secretary-General formally requesting UN assistance for the assessment and initial repairs of the oil tanker. The UN agreed to cover all the costs associated with the extraction and sale of the oil and the disposal of the vessel. ${ }^{28}$ However, in the spring of 2018 , the fighting escalated again, and the tensions prevented any work on the SAFER. In August 2019, the UN deployed a team of experts to Djibouti, based on an agreement from all parties. However, the Houthis made access to the SAFER conditional on the deployment of the UN Verification and Inspection Mechanism (UNVIM) ${ }^{29}$ for Yemen in the port of Hodeidah - as agreed in the Stockholm Agreement. ${ }^{30}$

25 Ibid.

26 Final Report of the Panel of Experts on Yemen (n 2) 170.

27 Ibid.

28 Ibid., 171.

29 The UnVIM was instituted to ensure compliance with the Resolution of the Security Council 2216 for the vessels sailing to the ports of Yemen not under the control of the government. UNVIM facilitates the flow of commercial items through verification and inspection at the ports are Hodeidah and Saleef. In particular, UNVIM grants clearances for vessels transporting commercial cargo destined for Yemen Red Sea ports. UNSC Res 2216 (14 April 2015) UN Doc S/RREs/2216, paras. 14-17. Moreover, the 2018 Stockholm Agreement states: 'A UN leading role in supporting Yemen Red Sea Ports Corporation in management and inspections at the ports of Hodeidah, Salif and Ras al-Isa, to include enhanced UNVIM monitoring in the ports of Hodeidah, Salif and Ras Issa'.

30 Stockholm agreement, Agreement on the City of Hodeidah and Ports of Hodeidah, Salif, and Ras Isa, 13 December 2018. It provides: 'A UN leading role in supporting Yemen Red Sea Ports Corporation in management and inspections at the ports of Hodeidah, Salif and Ras al-Isa, to include enhanced UNVIM monitoring in the ports of Hodeidah, Salif and 
Nevertheless, the UNVIM deployment in Hodeidah is subject to mutual agreement by the parties, and the government of Yemen is objecting to it. ${ }^{31}$ Thus, the technical mission was cancelled after the de facto Houthi authorities withdrew their approval. ${ }^{32}$

The negotiations with the Houthis to deploy a UN technical mission to the SAFE R started again following a leak of seawater into the SAFER engine room in May 2020. In particular, the UN has been engaging with the de facto authorities to agree on a detailed scope of work for the proposed mission, which should have three main objectives: an assessment of the conditions of the SAFER oil tanker, an urgent initial maintenance that might reduce the risks of an oil spill until a permanent solution is found; and a formulation of a set of options to permanently remove the threat of an oil spill in the Red Sea. ${ }^{33}$ Since mid-202O, the UNSC is starting to play a role in dealing with the risk of an environmental disaster linked to a possible oil spill due to the poor maintenance of the SAFER vessel over several years.

\subsection{The Role of the UN Security Council}

In July 2020, the Houthi authorities sent a formal note verbale to the UN informing them that they would accept the assessment and initial repair mission. They also sent a copy of this same note verbale to the President of the UNSC and requested that it be distributed to all Council members. Based on the note verbale, the UN submitted another official request for the assessment mission to the Houthi authorities. A special UNSC meeting was thus dedicated to the SAFER in July 2020.

The UNSC called the Houthis 'to immediately grant unconditional access for United Nations, technical experts, to assess the tanker's condition, conduct any possible urgent repairs, and make recommendations for the safe extraction of the oil'. ${ }^{34}$ UNEP briefed the Council about the environmental, humanitarian, and economic consequences of a leak or fire in the SAFER tanker. The UNEP has emphasized the necessity to put in place preventive measures to avoid an

Ras Issa'. This action point has not been yet implemented. For an overview of the agreement, see, Haydeee Dijkstal, 'Yemen and the Stockholm Agreement: Background, Context, and the Significance of the Agreement' (2019) 23 ASIL Insights 5 <https://www.asil.org/ insights/volume/23/issue/5/yemen-and-stockholm-agreement-background-context-and -significance>.

$31 \quad$ Final Report of the Panel of Experts on Yemen (n 2) 171.

$32 \quad$ Ibid.

33 Questions and answers about the UN Mission to the SAFER Oil Tanker in Yemen (n 1).

34 United Nations, 'Security Council Press Statement on Yemen' (sc/14233, 29 June 2020) $<$ https://www.un.org/press/en/2020/sc14233.doc.htm>. 
environmental disaster in the Red Sea. It also underlined the need to start with a technical assessment mission and light repair. However, in the long-term, it would be necessary to offload the oil from the SAFER and to dismantle the tanker in an environmentally sound manner. ${ }^{35}$

In November 2020, the UN received an agreement from the government and the Houthis on the objectives of the assessment mission. The Office of the Special Envoy of the Secretary-General for Yemen started the logistical preparations for the mission, which has yet to be deployed. ${ }^{36}$ In February 2021, the UNSC adopted a resolution with strong language concerning possible oil spills caused by the SAFER tanker. After having emphasized 'the environmental and humanitarian risk and the need, without delay, for access of UN officials to inspect and maintain the SAFER oil tanker, which is located in the Houthi-controlled north of Yemen, and stressing Houthi responsibility for the situation and for not responding to this major environmental and humanitarian risk', the UNSC underscored 'the need for the Houthis to urgently facilitate unconditional and safe access for United Nations experts to conduct an assessment and repair mission without further delay' and ensure 'close cooperation with the United Nations.' ${ }^{37}$

The Houthis, as an organized armed group, are bound by the rules of $\mathrm{IHL}^{38}$ While IHL is the lex specialis during armed conflicts, IHL does not operate in isolation from other areas of international law. Principles of international disaster law and international environmental law complement the rules of $\mathrm{IHL}$ to address the risks of an oil spill or an explosion of the SAFER tanker. The next section will look at the different legal frameworks, namely, IHL, international disaster law, and international environmental law applicable to address a potential environmental disaster during an armed conflict.

\section{Environmental Disasters in Time of Armed Conflicts: the Role} of International Humanitarian Law

As the situation in Yemen is classified as a non-international armed conflict, IHL is one of the areas of international law which is applied to the SAFER tanker. Yemen is a party to the 1949 Geneva Conventions and the 1977

United Nations Environment Programme, 'Briefing to the Security Council on the situation of Yemen' (16 July 2020) <https://www.unep.org/news-and-stories/speech/briefing -security-council-situation-yemen>.

36 Final Report of the Panel of Experts on Yemen (n 2) 170, para. 4.

37 UNSC Res 2564 (n 19).

38 Final Report of the Panel of Experts on Yemen (n 2) 43, para. 137. 
Protocols. Besides, the Government of Yemen and the Houthis, as parties to the armed conflict, have obligations under relevant customary IHL. The application of IHL also includes territorial waters where a non-state armed group exercises its de facto control. In particular, in the case of non-international armed conflicts, IHL is applicable in the whole territory under the control of a party, whether or not the conduct of hostilities takes place there. ${ }^{39}$ Therefore, the application of IHL is not restricted to the territory in which hostilities are being conducted. Hence, all parties to the conflict are bound by the rules of IHL of non-international armed conflict, and particularly the customary IH L rules protecting the natural environment must be respected. These rules are particularly relevant since the Protocol Additional to the 1949 Geneva Conventions, and relating to the Protection of Victims of Non-International Armed Conflicts (Protocol II), unlike the Protocol Additional to the 1949 Geneva Conventions, and relating to the Protection of Victims of International Armed Conflicts (Protocol I) does not include specific rules on the environment.

According to the customary law study of the ICRC, the rules protecting the 'natural environment' form part of customary IHL applicable to noninternational armed conflicts. To that end, it identified three specific customary law rules. First, it recognized the application of general principles on the conduct of hostilities to the natural environment. This includes, for example, that 'no part of the natural environment may be attacked unless it is a military objective. ${ }^{40}$ Second, methods and means of warfare must be employed with due regard to the protection of the environment. ${ }^{41}$ Third, Rule 45 affirms that 'the use of methods or means of warfare that are intended, or maybe expected, to cause widespread, long-term and severe damage to the natural environment is prohibited' and it adds that the 'destruction of the natural environment may not be used as a weapon'. While the ICRC database on customary IHL indicates that the first rule is applied in both typologies of armed conflicts, a more nuanced position is taken in regard to Rules 44 and 45 stating that they "arguably" apply in non-international armed conflicts. ${ }^{42}$

39 Sarah Williams and Gabrielle Simm, 'Assistance to disaster victims in an armed conflict. The role of International Humanitarian Law', in Flavia Zorzi Giustiniani, Emanuele Sommario, Federico Casolari and Giulio Bartolini (eds), Routledge Handbook of Human Rights and Disasters (Routledge 2018) 46. ICRC, 'Customary IHL Database, Rule 43A' <https://ihl-databases.icrc.org/customary-ihl/ eng/docs/v1_rul_rule43>.

41 ICRC, 'Customary IHL Database, Rule 44'<https://ihl-databases.icrc.org/customary-ihl/ eng/docs/vi_rul_rule44>.

42 ICRC, 'Customary IHL Database Rule 45'<https://ihl-databases.icrc.org/customary -ihl/eng/docs/vi_rul_rule45>; Michael Bothe, Carl Bruch, Jordan Diamond and David 
Moreover, one should consider the relevant provisions of IHL dealing with humanitarian assistance, particularly in non-international armed conflicts, and if such norms apply in the context of the prevention of an environmental disaster. There are a few provisions in IH L regulating humanitarian assistance in non-international armed conflicts, i.e., the common Article 3 to the Geneva Conventions and Article 18 of Protocol II. These provisions only deal with the consignments of essential goods such as foodstuffs, medical supplies, and clothing. ${ }^{43}$ Moreover, both provisions are subject to the consent of the state. ${ }^{44}$ Except for the right of humanitarian initiative (the right to offer services) for impartial humanitarian organizations, IHL provisions do not specifically address the role of UN agencies, regional organizations, or non-governmental organizations that could intervene in a situation such as the SAFER vessel.

The content of the principles and rules of IHL suggest that this body of law might not be ideal for adequately addressing the prevention of a potential environmental disaster such as an oil spill linked to the SAFER tanker. In particular, in the context of a non-international armed conflict, such as in Yemen, IHL would require that the consequences of the disaster reach the threshold where the survival of the civilian population is in danger and only deals with the transit and consignment of food, medical and clothing supplies. ${ }^{45}$

IHL is not the only legal framework applicable in the armed conflict in Yemen. For example, the application of human rights law and IHL has been recognized by various $U N$ bodies, including the International Court of Justice ${ }^{46}$ and the International Law Commission. ${ }^{47}$ The Guidelines on the Protection of the Natural Environment in Armed Conflict of the International Committee of the Red Cross (ICRC) 2020 also points out that in addition to rules of IHL, other rules of international treaty and customary law, including principles and rules of international environmental law and the law of the sea may continue to

Jensen, 'International Law Protecting the Environment During Armed Conflict: Gaps and Opportunities' (2010) 92 International Review of the Red Cross 879, 569, 569-592.

43 Williams and $\operatorname{Simm}(\mathrm{n} 39) 46$.

44 Ibid., 48.

45 Ibid., 5 o.

46 ICJ, Legal Consequences of the Construction of a Wall in the Occupied Palestinian Territory, (Advisory Opinion) [2004] ICJ Rep 2004, para. 106; ICJ, Armed Activities on the Territory of the Congo (Democratic Republic of the Congo v. Uganda) (Judgment Merits) [2005] ICJ Rep 2005, para. 216.

47 ILC, 'Text of the draft principles on protection of the environment in relation to armed conflicts', adopted by the Commission on first reading, Report of the International Law Commission, Seventy-first session' (29 April-7 June; 8 July-9 August 2019) UN Doc. $\mathrm{A} / 74 / 10,217$. 
apply during non-international armed conflicts. ${ }^{48} \mathrm{~A}$ similar approach has also been taken by the ILC Draft Principles on the Protection of the Environment in Relation to Armed Conflicts, adopted on its first reading in 2019. As affirmed in its Article 2, the Draft Principles aim 'at enhancing the protection of the environment in relation to armed conflict, including through preventive measures for minimizing damage to the environment during armed conflict and through remedial measures. ${ }^{49}$

In the context of the analysis of the application of treaties during armed conflicts, the ILC's 2011 Draft Articles on the Effects of Armed Conflicts on Treaties also provides a useful tool for interpretation. In particular, Article 3 states that ' $[\mathrm{t}]$ he existence of an armed conflict does not ipso facto terminate or suspend the operation of treaties: (a) as between States parties to an armed conflict; (b) as between a State party to the conflict and a State that is not'. Its Article 7 also provides an indicative list of treaties that would continue to apply during armed conflicts, including treaties relating to the protection of the environment and human rights law. ${ }^{50}$

As the paper will examine in the next section, international disaster law is relevant in the context of the definition of the legal framework that can be applied to the SAFER oil vessel. In this context, the 2016 ILC Draft Articles on Disasters are particularly significant. While Article 18 provides that ' $[t]$ he present draft articles do not apply to the extent that the response to a disaster is governed by the rules of [ $\mathrm{IHL}]^{, 51}$ in its commentaries, the ILC made clear that the situation of armed conflict does not exclude the application of the Draft Articles. This is particularly true

[I]n situations of 'complex emergencies' where a disaster occurs in an area where there is an armed conflict. A blank exclusion of the applicability of the draft articles because of the coexistence of an armed conflict would be detrimental to the protection of the persons affected by the disaster. $^{52}$

48 ICRC 'Guidelines on the Protection of the Natural Environment in Armed Conflict' (25 September 2020) 20.

49 Draft principles on protection of the environment in relation to armed conflicts (n 47) 211.

50 ILC, 'Draft articles on the effects of armed conflicts on treaties, with commentaries, Yearbook of the International Law Commission' 2011, vol. II (Part Two), 111 and 114 and its annex.

$5^{1} \quad$ ILC, 'Draft articles on the protection of persons in the event of disasters, Yearbook of the International Law Commission', 2016, vol. II (Part Two), article 18.

$5^{2} \quad$ Ibid., 73, para. 8. 
The ILC has included several principles in the 2016 ILC Draft Articles on Disasters which are similar to IHL rules such as humanitarian principles and the necessity to have the consent by the affected state to intervene in a disaster. ${ }^{53}$ Moreover, the ILC leaves open the possibility to make a resort 'to other applicable rules of international law'. ${ }^{4}$ This is relevant in the case of the SAFER tanker as the application of international disaster law and international environmental law is particularly helpful to prevent a technological disaster caused by an oil spill or a fire in the vessel. ${ }^{55}$

Before the analysis of the relevant principles and rules of international disaster law and international environmental law, the paper will address the question of the application of international law to non-state armed actors. to Non-State Armed Actors

The accepted threshold for the application of international law to non-state actors associated with de facto authorities is high, typically requiring control of territory and some form of administration. ${ }^{56}$ States cannot be held responsible for the actions of de facto entities existing beyond their control. Murray argues the necessity of subjecting the armed groups themselves to the rules of international law. ${ }^{57}$ This author also argues that de facto control theory provides a basis for the application of international environmental law and human rights law to non-state armed groups. ${ }^{58}$ De facto entities are regarded as 'independent

53 Giulio Bartolini, 'A Universal Treaty for Disasters? Remarks on the International Law Commission's Draft Articles on the Protection of Persons in the Event of Disasters' (2017) 99 International Review of the Red Cross 3, 1103, 1113.

54 Draft Articles on the protection of persons in the event of disasters ( $\left.n_{51}\right)$ art. 18.

55 For an analysis of the interaction between international disaster law, IHL and international environmental law, see Gabriella Venturini, 'International Disaster Response Law in Relation to Other Branches of International Law', in Andrea de Guttry, Marco Gestri and Gabriella Venturini (eds), International Disaster Response Law (Springer 2012) 58-6o. The author emphasizes the importance of the prevention principle in averting man-made disasters.

56 Daragh Murray, Human Rights Obligations of Non-State Armed Groups (Hart 2016) 133.

57 Ibid., p. 132.

58 Ibid., p. 120. 
entities that exist side-by-side with the established authorities' 59 and exercise "effective sovereignty". ${ }^{60}$

The de facto control theory is grounded in the principle of effectiveness and the factual circumstances at hand. It is the reality of effective control which forces the entity into an international place and demands the direct attribution of international rights and obligations. For example, the Inquiry Commission on Syria recognizes that armed groups are 'obligated to respect fundamental human rights norms, which form part of customary international law in the territory where such actors exercised de facto control. ${ }^{61}$ Moreover, in its Report of 2021, the Panel of Experts on Yemen identifies violations of IHL and human rights law attributable to the Houthis. ${ }^{62}$

The UN Group of Eminent International and Regional Experts on Yemen has noted that

The Non-State actors, such as Ansar Allah/Houthis, the de facto authorities in the northwest of Yemen, and the [sTC] in parts of the south of Yemen, cannot formally become parties to international human rights treaties. However, where these authorities exercise territorial control and government-like functions, they can be regarded as being bound by international human rights norms. ${ }^{63}$

A number of investigations mandated by the Human Rights Council or the UNSC on situations of armed conflicts have established the international legal obligations applicable to non-state armed groups on the basis of the de facto control theory. ${ }^{64}$ For international law to apply on this basis two criteria must be fulfilled: the non-state armed group must have the capacity to possess

59 Liesbeth Zegveld, The Accountability of Armed Opposition Groups in International Law (Cambridge University Press 2015) 15 .

6o Murray $\left(\mathrm{n}_{56}\right)^{121}$.

61 НR Council, 'Report of the Independent International Commission of Inquiry on the Syrian Arab Republic' (21 January 2021) UN Doc A/HRC/45/54, 12, para. 54.

62 Final Report of the Panel of Experts on Yemen (n 2) 42-44, paras. 134-142.

63 HR Council, 'Situation of human rights in Yemen, including violations and abuses since September 2014, Detailed findings of the Group of Eminent International and Regional Experts on Yemen' (29 September 2020) UN Doc A/HRC/45/CRP.7, 11, para. 29.

64 Ibid.; Final Report of the Panel of Experts on Yemen (n 2) 42-44, paras. 134-142; Report of the Independent International Commission of Inquiry on the Syrian Arab Republic (n 64) 12, para. 54; In general, see Andrew Clapham 'Focusing on Armed Non-State Actors' in Andrew Clapham and Paola Gaeta (eds) The Oxford Handbook of International Law in Armed Conflict (Oxford University Press 2014) 793-799. 
international obligations and the armed group must exist independently. ${ }^{65}$ If an armed group is "completely dependent" on a third state, then it is considered to be an organ of the state and is bound on the basis of that state's international obligations. Thus, in this last case, the armed group is not directly bound in its own right. This requirement does not preclude the possibility that an armed group may come under the partial authority of a third state. For instance, a third state may exercise control over certain activities of an armed group. In this case, the armed group remains however independent for those activities that are not under the control of the third state. ${ }^{66}$

While the accepted threshold associated with the de facto authorities is high, scholars have also argued that under appropriate situations, the actors falling below this threshold can become holders of international rights and obligations. For Murray 'armed groups existing below the threshold traditionally associated with de facto authorities may be bound consequent to the necessity-based application of international law' 67

The ILC Draft Principles on the Protection of the Environment in relation to Armed Conflicts adopted on first reading by the International Law Commission in 2019 has mainly focused on corporate due diligence and liability regimes for private companies, leaving aside threats by non-state armed groups. The extent of the obligations for non-state armed groups in respect to environmental protection has been defined by some authors as "the elephant in the room". 68 While some non-state armed groups have taken environmental commitments, ${ }^{69}$ the extent of the application of customary principles of international environmental law and international disaster law to non-state armed groups should be better scrutinized. If one makes parallelism with human rights law, one could argue that to the extent that non-state armed groups exercise de facto authority over a territory and government-like functions, these groups are also submitted to customary principles of international disaster law and international environmental law. Moreover, it could also be argued

\footnotetext{
$65 \quad$ Murray $\left(\mathrm{n}_{56}\right) 133$.

66 Ibid., 8.

$67 \quad$ Ibid., 133 .

68 Jonathan Somer, 'Non-state armed groups continue to cause environmental damage in conflicts, yet states are reluctant to meaningfully address their conduct for fear of granting them legitimacy' (Conflict and Environment Observatory (CEOBS), 4 December 2015) $<$ https://ceobs.org/environmental-protection-and-non-state-armed-groups-setting-a -place-at-the-table-for-the-elephant-in-the-room/>.

69 For examples of codes, commitments or policies of non-state armed groups that address the protection of the natural environment, see Somer (n 68).
} 
that there exists a duty of cooperation with the relevant actors involved in the preservation of the environment. The 2020 ICRC Guidelines on the Protection of the Natural Environment in Armed Conflict mention as an example that during the armed conflict in the Democratic Republic of the Congo, the government communicated with non-state armed groups regarding the maintenance of conservation efforts and protection of national parks. This communication was conducted in coordination with conservation organizations, UNESCO, and the UN Foundation. ${ }^{70}$

In the context of the analysis of the SAFER case study, the application of international disaster law to non-state armed groups is also raised. The paper argues that non-state armed groups also have to take into account the principles of prevention, mitigation, and preparedness of international disaster law. Given the application of human rights law and international environmental law to non-state armed groups, it can also be argued that international disaster law imposes duties to non-state armed groups.

\section{Principles of International Disaster Law and the Case of the SAFER Tanker}

The ILC Draft Articles on Disasters include 'large-scale environmental damage' that disrupt 'the functioning of society' in their definition of disasters. ${ }^{71}$ International disaster law is primarily concerned with 'a primary obligation to prevent harm to one's own population, property and the environment generally'72 and less with considerations of transboundary harm that are at the basis of the ILC Draft Articles on Prevention. Compared to the international environmental law, the spatial applicability of the principle of prevention in disaster law is expanded to the domestic context. ${ }^{73}$ The definition of disasters included in the ILC Disasters Articles includes both natural and technological disasters such as the risk of an oil spill or fire in the SAFER tanker. The ILC Draft Articles on Disasters are mainly focused on the protection of the needs of the persons affected by a disaster. On the contrary, international environmental law is more concerned about the prevention of damage to the environment

\footnotetext{
$70 \quad$ Guidelines on the Protection of the Natural Environment in Armed Conflict (n 48) 61.

71 Draft Articles on the protection of persons in the event of disasters (n 51$)$ art. 3 .

72 Leslie-Anne Duvic Paoli, The Prevention Principle in International Environmental Law (Cambridge University Press 2018) 84.

Ibid.
} 
per se and societal disruption is not a necessary element. ${ }^{74}$ On one hand, the ILC Prevention Articles point out that states have an obligation to anticipate emergencies by developing contingency plans and operating early warning systems. ${ }^{75}$ On the other, the ILC Special Rapporteur on the protection of persons in the event of disasters has included a 'duty to reduce the risk of disaster. ${ }^{76}$

While international environmental law is primarily concerned with the prevention of transboundary harm, international disaster law underlines the domestic dimension of the principle of prevention. Thus, this principle has a specific focus on the prevention of the risk of a disaster and the protection of the rights of persons who might be affected by such an event. ${ }^{77}$ Given the different scope of application of the principle of prevention in international environmental law and international disaster law, it is difficult to rely on the sources of the obligation in international environmental law to justify the customary status of this principle in international disaster law. Duvic-Paoli notes however that the principle of prevention should be viewed as 'a general principle of international law in the sense that the anticipatory perspective of some norms brings them together and facilitates a process of cross-fertilization between norms sharing a similar rationale. ${ }^{78}$

The cross-fertilization between international disaster law and international environmental law appears in the ILC Draft Articles on Disasters. ${ }^{79}$ Although in different ways, the principle of prevention is a common feature of these two areas of international law. In the frame of international disaster law, the principle of prevention has been recognized in draft Article 9 of the ILC Draft Articles on Disasters which provides that states have to reduce disasters 'through legislation and regulations to prevent, mitigate, and prepare for disasters'. The Article adds that these measures include '[to] conduct of risk assessments, the collection and dissemination of risk and past loss information, and the installation and operation of early warning systems' ${ }^{80}$ The ILC explains that this Draft Article relies on human rights law, especially the protection of the

74 Tim Stephens, 'Disasters, international environmental law and the Anthropocene' in Susan C. Breau, Katja L.H. Samuel (eds.), Research Handbook on Disasters and International Law (Edward Elgar 2016) 154-155. Draft articles on Prevention of Transboundary Harm from Hazardous Activities (n 10) art. 17 .

76 Draft Articles on the protection of persons in the event of disasters ( $\left.n_{51}\right)$ art. 9.2.

77 Duvic-Paoli (n 72$) 84$.

78 Ibid., 85 .

79 For a discussion on this topic, see Tim Stephens (n 74) 153-176.

8o Draft Articles on the protection of persons in the event of disasters ( $\left.n_{51}\right)$ art. 9. 
right to life ${ }^{81}$ but also on the concept of due diligence enshrined in international environmental law. ${ }^{82} \mathrm{As}$ in the case of international environmental law, the duty to take preventive measures to reduce the risks of an environmental disaster is an obligation 'of conduct and not result'.83 The ILC specifies that the duty to reduce disaster risk is achieved by taking certain measures to prevent, mitigate and prepare for such disasters. ${ }^{84}$

The principle of prevention should be read together with the concepts of mitigation and preparedness. The objective is to reduce the risk of harm and not to completely prevent a disaster. ${ }^{85}$ The terms of "prevention", "mitigation" and "preparedness" are used in various policy instruments. ${ }^{86}$ Moreover, the United Nations Office for Disaster Risk Reduction and the open-ended intergovernmental expert working group on indicators and terminology relating to disaster risk reduction have provided a definition of these terms. ${ }^{87}$ According to the expert working group, prevention is defined as the 'activities and measures to avoid existing and new disaster risks', mitigation includes 'the lessening or minimizing of the adverse impacts of a hazardous event', and preparedness includes the 'knowledge and capacities developed by governments, response and recovery organizations, communities and individuals to

81 In this context, the ILC also mentions the jurisprudence of the European Court of Human Rights in support of its arguments saying that the European Court of Human Rights in its judgments in the 'Öneryildiz and Others v. Turkey' and 'Budayeva and Others v. Russia' cases affirmed the duty to take preventive measures. Draft Articles on the protection of persons in the event of disasters ( $\left.n_{51}\right) 22$.

$82 \quad$ Ibid.

83 Ibid., 23.

84 Ibid., 26.

85 Ibid.

86 The ILC gives details about the wide range of instruments including the duty to reduce the risk of disasters. Ibid., 22-23.

87 According to the terminology of the United Nations Office for Disaster Risk Reduction, 'Prevention [is] [t] he outright avoidance of adverse impacts of hazards and related disasters. Prevention (i.e. disaster prevention) expresses the concept and intention to completely avoid potential adverse impacts through action taken in advance. Very often the complete avoidance of losses is not feasible and the task transforms to that of mitigation'. The term of "mitigation" is " $[\mathrm{t}$ ] he lessening or limitation of the adverse impacts of hazards and related disasters'. The term of "preparedness" includes the "knowledge and capacities developed by governments, professional response and recovery organizations, communities and individuals to effectively anticipate, respond to, and recover from, the impacts of likely, imminent or current hazard events or conditions'. Cited in Draft Articles on the protection of persons in the event of disasters ( $\left.n_{51}\right) 16$. 
effectively anticipate, respond to and recover from the impacts of likely, imminent or current disasters.' 88

However, these terms are not easily translated into specific legal obligations. The principle of prevention has been developed in a number of areas of international law, including international environmental law and human rights law, the principles of mitigation and preparedness have been developed more directly in the disaster context. Both principles can be considered as a dimension of the principle of prevention and better understood 'as activities to prevent or minimize disaster losses' ${ }^{89}$ For example, the development of contingency plans, early warning systems, and the collection of technical data and information are particularly important for the application of the principles of prevention, mitigation, and preparedness. The establishment of a preparedness plan would include the adoption of an arrangement between the government of Yemen and the Houthis that could enable a timely and effective response to a potentially hazardous event.

The principles of prevention, mitigation, and preparedness find also application in the ILC Draft Article 7 affirming an obligation to cooperate in the context of risk reduction and relief assistance. States are expected to cooperate among themselves as well as with the UN system. As recognized by the ILC Commentary 'effective international cooperation is indispensable for the protection of persons in the event of disasters. ${ }^{90}$ Disaster law is concerned with a greater variety of risks compared to international environmental law, not only environmental ones. This area of international law focuses on the harm of high intensity that 'seriously disrupts the functioning of society'. ${ }^{91}$ Therefore, the obligation to prevent is related to a specific timeframe and with a view to protecting the population and not necessarily the environment.

An oil spill or a fire in the SAFER tanker would affect the human rights of communities whose livelihoods depend on the Red Sea ecosystem. The disaster would also affect the marine environment of this fragile ecosystem. In order to prevent, mitigate and put in place adequate preparedness measures, the government of Yemen and the Houthis need to collaborate between themselves.

88 UNGA, 'Report of the open-ended intergovernmental expert working group on indicators and terminology relating to disaster risk reduction' (1 December 2016) UN Doc A/71/644, $20-21$.

89 Marie Aronsson-Storrier, 'Exploring the Foundations: The Principles of Prevention, Mitigation, and Preparedness in International Law' in Katja L.H. Samuel, Marie Aronsson-Storrier and Kirsten Nakjavani Bookmiller (eds), The Cambridge Handbook of Disaster Reduction and International Law (Cambridge University Press, 2019) 70.

90 Draft Articles on the protection of persons in the event of disasters ( $\mathrm{n} 51$ ) 17 .

$91 \quad$ Ibid., art. 3 (a). 
The government and the Houthis also need to cooperate with relevant UN agencies including OCHA and UNEP. The first step in this direction is to allow that a technical mission assesses the risks due to the lack of maintenance of the SAFER tanker.

As aforementioned, in 2006, Lebanon had requested assistance from the regional marine pollution emergency response center for the Mediterranean Sea (REM PEC). In compliance with Article 12 of the 2002 Protocol concerning cooperation in preventing pollution from the ship and, in cases of emergency, combating pollution of the Mediterranean Sea, ${ }^{92}$ the information was collected on the oil spill. Then, REM PEC issued a circular letter calling for assistance to the Focal Points of the Barcelona Convention. Lebanon also requested direct bilateral assistance. In accordance with the 2002 Protocol, REMPEC coordinated at the regional level the response operations to the oil spill in collaboration with UNEP, OCHA, and the International Maritime Organization (IMO). ${ }^{93}$ The first phase of the clean-up operation in Lebanon was completed in February 2007. According to REMPEC 'a total amount of $7,280 \mathrm{~m}_{3}$ of contaminated waste was collected including 1,o26 $\mathrm{m} 3$ of liquid oil, $238 \mathrm{~m} 3$ of semi-solid oil and 6,o16 $\mathrm{m} 3$ of polluted sand. ${ }^{94}$ During the hostilities, the Lebanese national authorities were prevented to put in place measures to contain the oil near the site of the spillage. By August 2006, the oil spill also reached the coast of Syria. Several on-site missions took place, including experts from REMPEC, the UNEP/OCHA Environment Unit, and IMO. ${ }^{95}$

\section{The Application of International Environmental Law to the Case of the SAFE R Tanker}

In international environmental law, it is well known that environmental protection is best ensured through the prevention of damage since the damage

92 Protocol concerning cooperation in preventing pollution from ship and, in cases of emergency, combating pollution of the Mediterranean Sea, 25January 2002, art. 12.1 ('Any Party requiring assistance to deal with a pollution incident may call for assistance from other Parties, either directly or through the Regional Centre, starting with the Parties which appear likely to be affected by the pollution. This assistance may comprise, in particular, expert advice and the supply to or placing at the disposal of the Party concerned of the required specialized personnel, products, equipment and nautical facilities. Parties so requested shall use their best endeavours to render this assistance').

REMPEC's Involvement in the Marine Pollution Incident in the Eastern Mediterranean During the Summer 2006 (n 4) para. 7.

94 Ibid., para. 25.

$95 \quad$ Ibid., paras. 19-22. 
to the environment is often irreversible or the restoration before the damage can be impossible or involve a very high cost. The prevention principle has been defined as 'an anticipatory principle that seeks to avoid foreseeable risks' and requires that 'States (and other subjects) exercise due diligence in the face of environmental risks. As such, States are not merely expected to exercise restraint vis-à-vis environmental harm but are required to take positive steps to protect the environment. ${ }^{96}$

The principle of prevention has been developed as a central principle in the regulation of transboundary harm. In the 'Trail Smelter' case, the arbitral tribunal found that

$[\mathrm{U}]$ nder the principles of international law [...] no State has the right to use or permit the use of its territory in such a manner as to cause injury by fumes in or to the territory of another or the properties or persons therein when the case is of serious consequences and the injury is established by clear and convincing evidence..$^{97}$

In the beginning, this obligation was centred around the protection of sovereign rights, rather than the protection of the environment. However, over the years, this principle has been linked to environmental protection and the obligation of due diligence. In this respect, the principle of prevention of transboundary harm was affirmed in the 1996 International Court of Justice's (ICJ) Advisory Opinion on the 'Legality of the Threat or Use of Nuclear Weapons', stating that

[T] he Court also recognizes that the environment is not an abstraction but represents the living space, the quality of life, and the very health of human beings, including generations unborn. The existence of the general obligation of States to ensure that activities within their jurisdiction and control respect the environment of other States or of areas beyond national control is now part of the corpus of international law relating to the environment. ${ }^{98}$

$96 \quad$ Duvic-Paoli (n 72$) 8$.

97 UN Reports of International Arbitral Awards (Un RIAA), 'Trail Smelter Case (United States v. Canada)' [1941] (Awards of 16 March 1938 and 11 March 1941) 3 UnRIAA (1941), 1905-1965.

98 ICJ, 'Legality of the Threat or Use of Nuclear Weapons' (Advisory Opinion) [1996] ICJ Rep 1996 (I), 242, para. 29. 
The link between the principle of prevention and transboundary harm has been expressly recognized in the 2001 ILC Draft Articles on Prevention. The Draft Articles require states 'to take all appropriate measures to prevent significant transboundary harm at any event to minimize the risk thereof'. ${ }^{9}$ In its commentary, the ILC indicates that the duty 'to take preventive or minimization measures is one of due diligence ${ }^{100}$ and that the obligation of due diligence should be viewed as 'the standard basis for the protection of the environment from harm. ${ }^{101}$ Article 16 of the ILC Prevention Draft Articles includes several elements which are relevant to environmental emergencies. For example, Article 16 provides that the state of origin of transboundary harm 'shall develop contingency plans for responding to emergencies, in cooperation, where appropriate, with the State likely to be affected and competent international organisations'. Article 17 also stipulates the obligation of notification to states likely to be affected by an emergency. The ILC indicates that these provisions reflect general obligations relying on international practice in several fields of international law including in the law of the sea.

Moreover, in the 'Pulp Mills on the Uruguay River' case, the ICJ specified the contours of the due diligence obligation and the prevention of transboundary harm. In particular, it affirmed that

[T] he principle of prevention, as a customary rule, has its origins in the due diligence that is required of a State in its territory. It is "every State's obligation not to allow knowingly its territory to be used for acts contrary to the rights of other States" (Corfu Channel (United Kingdom v. Albania), Merits, Judgment, I.C.J. Reports 1949, p. 22). A State is thus obliged to use all the means at its disposal in order to avoid activities which take place in its territory, or in any area under its jurisdiction, causing significant damage to the environment of another State. This Court has established that this obligation "is now part of the corpus of international law relating to the environment" (Legality of the Threat or Use of Nuclear Weapons, Advisory Opinion, I.C.J. Reports 1996 (I), p. 242, para. 29). ${ }^{102}$

The extent of the application of the principle of prevention to non-state armed groups such as the Houthis might raise several questions. This paper

99 Draft articles on Prevention of Transboundary Harm from Hazardous Activities (n 1o) art. 3 .

100 ILC, 'Yearbook of the International Law Commission', 2001, vol. II (Part Two), 154, para. 7.

101 Ibid., 154, para. 8.

102 ICJ, 'Pulp Mills on the River Uruguay' (Argentina v. Uruguay) (Judgment Merits) [2010] ICJ Rep 2010, 55-56, para. 101. 
argues that given the de facto control over the vessel and the territorial sea in Northern Yemen, both the government of Yemen and the Houthis should take measures to prevent significant damage to the environment including through risk assessments, collection of data on the conditions of the vessel and preparedness measures in case of an oil spill or an explosion.

Another question is whether environmental or human rights treaties are binding on non-state armed groups. The ILC Draft Articles on the Effects of Armed Conflicts on Treaties specify that the Draft Articles also cover noninternational armed conflicts. Recognizing that 'non-international armed conflicts could affect the operation of treaties as much as international ones could. The draft articles, therefore, include the effect on treaties of noninternational armed conflicts'.103 However, two requirements should be met: the armed group must be 'organized' and the type of armed conflict needs to be 'protracted'. ${ }^{104}$ As already noted, the ILC has developed a list of treaties whose subject matter involves that they continue to be operational during armed conflicts. This list includes 'multilateral law-making treaties', 'treaties relating to the international protection of the environment' and 'treaties for the international protection of human rights.' 105

In the context of the SAFER tanker, the treaties regarding the protection and preservation of the marine environment are particularly relevant. At the global level, UNCLOS affirms the obligation 'to protect and preserve the marine environment'.106 The UNCLOS contains several provisions in Part XII that seek to minimize the risk of environmental disasters from accidents at sea. For example, according to Article 198, when a state becomes aware of a situation in which the marine environment is in imminent danger of being damaged, or has been harmed by pollution, it must notify other states that are likely to be affected by the pollution. Moreover, Article 199 affirms that states in the areas affected must, in accordance with their capabilities, cooperate in eliminating the effects of pollution and preventing or minimizing the damage. Moreover, when a pollution emergency occurs within the jurisdiction or control of a state and there is the risk to affect other states, Article 194.2 indicates an obligation to take reasonable steps to prevent this transboundary effect from occurring. These general obligations enshrined in UNCLOS are elaborated

\footnotetext{
103 Draft articles on the effects of armed conflicts on treaties, with commentaries, Yearbook of the International Law Commission (n 50 ) 110, para. 8.

104 Ibid., 111, para. 8.

105 Ibid., Annex, 122 (c), 126 (f) and 127 (g).

106 UNCLOS (n 8) art. 192.
} 
and extended in the 1990 Convention on Oil Pollution Preparedness, Response, and Cooperation and the 2000 Protocol on Preparedness, Response and Cooperation to Pollution Incidents by Hazardous and Noxious Substances.

The impact of a potential disaster due to an oil spill would have a widespread and long-term impact on the marine ecosystem. The Red Sea is one of the world's richest and most biodiverse marine ecosystems: home to endemic fish species, mangroves, and coral reefs. ${ }^{107}$ In addition to the environmental impact, an oil leak would also affect the populations living along the coast. Moreover, the closure of the port for the clean-up would also have an impact on the humanitarian assistance delivered to the population of Yemen and aggravate the famine already existing in this country.

Although not directly related to the case of Yemen, the case-law of the European Court of Human Rights confirms and elaborates on the positive obligations by states in relation to the protection of human rights which illustrates the strong linkage between international environmental law and human rights law and at the same time also provide foundations for disaster risk reduction measures. ${ }^{108}$ Technological disasters may affect a number of human rights. Thus, a state should take preventive measures to ensure that technological hazards do not affect human rights. The state's obligation is not only a negative one - requiring states to restrain from creating environmental harm that may affect human rights - but also a positive one. States have to take proactive measures to avoid environmental harm within their domestic territory. However, it is necessary to show a link between the environmental harm and the human rights affected. ${ }^{109}$ An oil spill caused by the sink or explosion of the SAFER tanker would affect a number of human rights, including the right to life, the right to food, and the right to health.

Some cases of the European Court of Human Rights illustrate the linkages between environmental harm, human rights, and the duty to prevent an environmental disaster. For example, in the 2004 case of 'Öneryldız and others v. Turkey' concerning a methane explosion which resulted in 39 people losing their lives and significant destruction of slum dwellings, the Court concluded that the failure of Turkey to take precautionary measures was in breach of the right to life and the right to property. The Court affirmed that the right to life

\footnotetext{
107 Joseph Hinks, 'A rusting oil tanker off the coast of Yemen is an environmental catastrophe waiting to happen. Can anyone prevent it?' (The Time, 24 May 2021) $<$ https://time .com/6o48436/fso-safer-yemen-oil-tanker-disaster/>.

108 ECHR, 'Önerylldız and others v. Turkey', Judgement, (3o November 2004).

109 Duvic-Paoli (n 72) 249.
} 
'does not solely concern deaths resulting from the use of force by agents of the State but also ... lays down positive obligations on States to take appropriate steps to guard the lives of those within their jurisdiction. ${ }^{\prime 10}$ Another example is the case 'Budayeva and others v. Russia'. A dam was seriously damaged in August 1999 and despite repeated calls was not repaired before the next mudslide season. In July 200o, a mudslide destroyed the dam and caused severe destruction, resulting in eight people dead and 19 allegedly missing people. The Court affirmed that since the authorities were aware of the risk of the damage caused by the precarious conditions of the dam and that mudslides were common, Russian authorities should have been better prepared and ensured that a proper early warning system was in place. ${ }^{111}$ The authorities failed to set up 24-hour observation posts, despite repeated calls for the need for enhanced monitoring of the river and they also failed to inform the population about the risk. ${ }^{12}$ Significantly, the Court also affirms that 'there was no justification for the authorities' omission in implementation of the land-planning and emergency relief policies in the hazardous area of Tyrnauz regarding the foreseeable exposure of residents, including all applicants, to mortal risk'.113 This case indicates the duty of a state to take preventive measures such as emergency relief policies and early warning systems to avoid negative impacts on the population.

From the above analysis, this paper argues that both the government of Yemen and the non-state armed groups are bound by international environmental law and humanitarian law. Given the de facto control over the territory, the organized character, and the protracted nature of the conflict, the Houthis should respect customary principles of international environmental law such as the principle of prevention and the duty of due diligence. Moreover, the actions of the Houthis should not be contrary to multilateral treaties such as the UN Convention on the Law of the Sea which contains an obligation to protect the marine environment. As we will see in the next section, there are also a number of regional treaties protecting the Red Sea which should also be respected by the Houthis.

\footnotetext{
110 Öneryldız and others v. Turkey (n 108) para. 71.

111 ECHR, 'Budayeva and Others v. Russia', Judgment, (2O March 2008), paras. 152, 154 and 156.

112 See K.C. Lauta, 'Human rights and natural disasters' in S. Breau and K.L.H. Samuel (eds.), Research Handbook on Disasters and International Law (Edward Elgar, 2016) 91.

113 Budayeva and Others v. Russia (n 111) 158.
} 
The marine area where the SAFER tanker is anchored is a specially protected zone under the Programme for the Environment of the Red Sea and Gulf of Aden (PRSGA) which was initiated in 1974. Moreover, the Red Sea is also a special area under the MARPOL Convention on marine pollution. ${ }^{114}$ This region is globally known for the unique character of its marine biodiversity and its special economic, historical and social values. Some of its sites have a global value including the Socotra Archipelago which is considered a UNESCO Natural Heritage Site. ${ }^{115}$ Moreover, the Farsan (near Saudi Arabia) and Dahlak (near Eritrea) Archipelagos in the southern Red Sea are also known for their coral reefs. An oil spill caused by the lack of maintenance of the SAFER tanker would have a catastrophic impact on this fragile ecosystem.

In 1982, this region's coastal states signed the Jeddah Convention. ${ }^{16}$ This instrument is in line with the Convention on the Law of Sea which calls for cooperation among coastal states of an enclosed or a semi-enclosed sea. ${ }^{117}$ The Jeddah Convention includes provisions on the rights and duties of States concerning marine environmental protection. This instrument also establishes

114 International Convention for the Prevention of Pollution from Ships (MARPOL Convention), 2 November 1973, Annex I: Regulations for the Prevention of Pollution by Oil, art. 1.

115 UneSCO, 'World Heritage List' <https://whc.unesco.org/en/list/?type=natural>.

116 Regional Convention for the Conservation of the Red Sea and Gulf of Aden Environment (n 9); Protocol concerning Regional Cooperation in Combating Pollution by Oil and other Harmful Substances in Cases of Emergency, 14 February 1982. The following States are parties to the Jeddah Convention: Djibouti, Egypt, Jordan, Saudi Arabia, Somalia, Sudan and Yemen; UneP Regional Seas Report and Studies, 'Action Plan for the Conservation of the Marine Environment and Coastal Areas in the Red Sea and Gulf of Aden' (1986) < https://www.unep.org/resources/report/ action-plan-conservation-marine-environment-and-coastal-areas-red-sea-and-gulf $>$.

117 UNCLOS (n 8) art. 123 'States bordering an enclosed or semi-enclosed sea should cooperate with each other in the exercise of their rights and in the performance of their duties under this Convention. To this end they shall endeavour, directly or through an appropriate regional organization: (a) to coordinate the management, conservation, exploration and exploitation of the living resources of the sea; (b) to coordinate the implementation of their rights and duties with respect to the protection and preservation of the marine environment; (c) to coordinate their scientific research policies and undertake where appropriate joint programmes of scientific research in the area; (d) to invite, as appropriate, other interested States or international organizations to cooperate with them in furtherance of the provisions of this article'. 
the Regional Organization for the Conservation of the Environment of the Red Sea and Gulf of Aden (PERSGA). ${ }^{118}$

Together with the Jeddah Convention, the coastal states of the Red Sea also adopted two other important instruments - the Action Plan for the Conservation of the Marine Environment and Coastal Areas in the Red Sea and the Gulf of Aden and the Protocol concerning Regional Cooperation in Combating Pollution by Oil and Other Harmful Substances in Cases of Emergency (the 1982 Protocol). ${ }^{119}$ Under the 1982 Protocol, an Emergency Mutual Aid Center in the Red Sea and Gulf of Aden (EMARSGA) has been established. ${ }^{120}$ This Center provides technical assistance to the countries of the region in the preparation of national contingency plans to prepare for and respond to incidents of contamination with oil and other harmful substances, in cooperation with the International Maritime Organization (IMO). ${ }^{121}$ In particular, it could support the development of contingency plans to enhance preparedness to mitigate the environmental impacts of a potential spill. While prevention efforts are the primary focus for securing the vessel, adequate preparedness in case of a spill is also essential to ensure a timely and coordinated response to mitigate the severity of the impacts of a spill occurs.

IMO may provide technical support and advice to governments faced with a significant oil spill. This is nevertheless conditional to a request for assistance from the country. IMO could support the PERSGA's efforts by providing technical advice. PERSGA, through its Emergency Mutual Aid Center in the Red Sea and the Gulf of Aden, is expected to play a key role in the coordination of the preparation of contingency plans and response efforts in line with the 1982 Protocol. According to this instrument, the Center has the right to initiate operations to combat pollution by oil and other harmful substances at the regional level. ${ }^{122}$ PERSGA has also promoted the development of marine protected areas off the Yemen coast. One of these, Kamaran Island, lies around

\footnotetext{
118 Regional Convention for the Conservation of the Red Sea and Gulf of Aden Environment (n 9) art. XVI.

119 Regional Convention for the Conservation of the Red Sea and Gulf of Aden Environment (n 9); Action Plan for the Conservation of the Marine Environment and Coastal Areas in the Red Sea and Gulf of Aden ( $\mathrm{n}$ 116); Protocol concerning Regional Cooperation in Combating Pollution by Oil and other Harmful Substances in Cases of Emergency (n 119).

120 Protocol concerning Regional Cooperation in Combating Pollution by Oil and other Harmful Substances in Cases of Emergency (n 119) art. III.

121 Ibid., art. III (3) (b) (ii) and art. III (3) (f).

122 Ibid., art. III (2) (c).
} 
$14 \mathrm{~km}$ north from where the SAFER is anchored. ${ }^{123}$ It is clear that the SAFER presents a serious risk to this marine protected area and the wider Red Sea.

The ongoing conflict in Yemen has a significant impact on the development of contingency planning. There are several challenges in collecting complete and updated information. The current situation would also affect the capacity for a response in case of an oil spill. ${ }^{124}$ It seems inevitable that the conflict would limit access to affected areas, restrict the availability of equipment necessary to tackle the spill, and require international financial and technical assistance. Dealing with this threat requires cooperation between the parties to the conflict and UN institutions. The use of the environmental and humanitarian threats posed by the SAFER vessel as a bargaining chip by the Houthis risk undermining the joint efforts to find a technical solution to the prevention of an environmental disaster.

In order to prevent an environmental and humanitarian disaster, it is necessary to unload the oil from the SAFER vessel. However, this requires cooperation between the UN, the Yemeni government, and the Houthis who still control the port terminal. A spill from the vessel would have serious consequences for the marine environment. The Exxon Valdez disaster involved 26o.ooo barrels which are just a fraction of what the SAFER is believed to contain. The spill would also heavily affect the mangroves and coral reefs supporting local fisheries.

The importance of the issues at stake dealing with the SAFER tanker is showed by the involvement of the UNSC. The first time when this issue was discussed before the UNSC was in April 2019 when the UN's UnderSecretary-General for Humanitarian Affairs and Emergency Relief Coordinator, Mark Lowcock, drew attention to the threat posed by the tanker. In February 2021, the UNSC stated 'the need for the Houthis to urgently facilitate unconditional and safe access for United Nations experts to conduct an assessment and repair mission without further delay' and ensure 'close cooperation with the United Nations.'.125

123 See PERSGA, 'Social and Environmental Assessment in Kamaran, Yemen' <http://sem .persga.org/socila-and-env-assessment.php>.

124 IMO, 'FSO SAFER Oil Spill Risk' (4 June 2021), <https://www.imo.org/en/MediaCentre/ HotTopics/Pages/FSO-SAFER-oil-spill-risk.aspx $>$.

125 UNSC Res 2564 (n 19). 
Several questions remain open in relation to the role of the UN in preventing the risk of an environmental disaster in the Red Sea. It has been proposed that the UNSC could make a special case for the vessel and establish a special mechanism to oversee the unloading and sale of the oil. However, the question remains on how to proceed with the split of the revenues from selling the oil between the different parties. Another option would be to leave the tanker in place and mitigate any risks through restarting maintenance, again overseen by the UN. ${ }^{126}$

The vessel could only be safely offloaded if conducted in a safe place where it can be repaired. However, in addition to the political difficulties, there are many other technical concerns such as insurance coverage, payments for those involved in the work, and the fate of the vessel and its oil. The problems raised by this situation are increasingly important as shown by the UNSC resolution adopted in February 2021. ${ }^{127}$

In order to prevent the risks of an environmental and humanitarian disaster, the UN will need to balance the different demands of the Houthis and the government of Yemen. The UNSC could create a specific mechanism to oversee and manage the sale of the SAFER's oil. The mechanism and process should be fully transparent and time-limited, to ensure that it proceeds and is concluded as swiftly as possible. This would require in any case that the Houthis ceases obstructing a UN technical assessment of the vessel.

\footnotetext{
126 Doug Weir, 'Time to move beyond Yemen's SAFER oil tanker blame game', Conflict and Environment Observatory - СЕОВ (1 Junes 2020) <https://ceobs.org/time-to-move -beyond-yemens-safer-oil-tanker-blame-game/>.

127 UNSC Res 2564 (n 19).
} 